\title{
The Early Sarmatian bryozoan Celleporina medoborensis sp. nov. from the Medobory reefs of western Ukraine (Central Paratethys)
}

\author{
Urszula HARA and Marek JASIONOWSKI
}

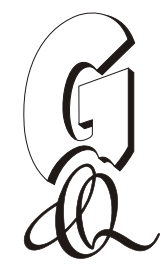

\begin{abstract}
Hara U. and Jasionowski M. (2012) - The Early Sarmatian bryozoan Celleporina medoborensis sp. nov. from the Medobory reefs of western Ukraine (Central Paratethys). Geol. Quart., 56 (4): 895-906, doi: 10.7306/gq.1064

Moundlike, globular to hemispherical bryozoan colonies of Celleporina medoborensis sp. nov. are documented from the calcareous organodetrital, slightly marly facies of the Lower Sarmatian (Volhynian) serpulid-microbialite reefs, in the Polupanivka and Ditkivtsi quarries (Medobory Hills), located at the northeastern margin of the Carpathian Foreland Basin (Central Paratethys) in western Ukraine. The colonies of $C$. medoborensis are multilamellar, often with a subcircular hole and occur together with numerous cyclostome bryozoans (crisiids, tubuliporinids, branching colonies of entalophoroids) as well as schizoporellid and cryptosulid cheilostomes, accompanied by a few macro- and micro-fossil taxa. The combination of morphological characters such as: thick radial ribs in the pseudoporous, variably-shaped area of the ovicell, and one or two small adventitious oral, as well as large vicarious avicularia are the main characteristic features of species. The rich occurrence of the celleporiform colonies of $C$. medoborensis sp. nov. within the fine-grained calcareous sands of Polupanivka and Ditkivtsi suggests a shallow-water setting and high availability of soft substrates, probably dominated by calcareous algae upon which the bryozoans may have settled in the Medobory reef biota during the Early Sarmatian.
\end{abstract}

Urszula Hara and Marek Jasionowski, Polish Geological Institute - National Research Institute, Rakowiecka 4, 00-975 Warszawa, Poland, e-mails: urszula.hara@pgi.gov.pl, marek.jasionowski@pgi.gov.pl (received: May 17, 2012; accepted: October 26, 2012; published online: December 17, 2012).

Key words: Bryozoa, taxonomy, serpulid-microbialite reefs, Lower Sarmatian, Middle Miocene, Ukraine, Paratethys.

\section{INTRODUCTION}

The Early Sarmatian (Middle Miocene) was a time when the benthic biota in the Paratethys was severely impoverished in comparison to the Late Badenian, due to the Badenian-Sarmatian extinction event (BSEE; see Moissette et al., 2006; Harzhauser and Piller, 2007; Tóth et al., 2010; Studencka and Jasionowski, 2011). In the Early Sarmatian the Paratethys became a semi-marine basin due to the restriction of connections with the World Ocean and a large excess of meteoric water input over evaporation (Studencka and Jasionowski, 2011).

The intensive geological and palaeontological studies of the classical sections of the large Pannonian Basin system, including the Vienna, Danube, and Zsámbék basins have contributed to several taxonomic works where bryozoans play an essential role (see Bobies, 1957; Vávra, 1979; Zágoršek and Fordinal, 2006; Fordinal et al., 2006; Moissette et al., 2007; Zágoršek, 2007; Cornée et al., 2009). The first mentions of the occurrence of Sarmatian bryozoan reefs in the Eastern
Carpathians appeared at the end of the 19th century (Olszewski, 1876; Hilber, 1882; Teisseyre, 1884, 1885). Reuss (1869), however, was the first to describe the Sarmatian bryozoan fauna from the Carpathian Foredeep of Kishiniev, after which Andrusov $(1899,1902)$ listed a few bryozoan taxa from the Eastern Carpathian region. Subsequently, Sarmatian bryozoans were described from a few areas of the Western Precaucasus, Kerch Peninsula, Moldavia, Romania and Volhyno-Podolia (Ghiurca, 1968; Ghiurca and Stancu, 1974; Bagdasaryan and Ponomareva, 1982; Vejs, 1988; Zágoršek et al., 2008).

The Early Sarmatian bryozoans are important constituents of the biologically-created accumulations of the northern Carpathian Foredeep of SE Poland and western Ukraine, occupying various ecological niches (e.g., Taylor et al., 2006). Recent investigations between 2001-2011 of the Lower Sarmatian (Volhynian) carbonate buildups (also called serpulid-microbialite reefs) of the Medobory Ridge of the western Ukraine (Jasionowski, 2006) have revealed rich and well-preserved bryozoan faunas. The species composition of 
the bryozoans, their spatial distribution in the reefs, as well as the colony growth-patterns are well-differentiated through the Sarmatian buildups, while their occurrence is influenced by different facies such as reef facies, marly and silty facies as well as organodetrital deposits. At the Polupanivka and Ditkivtsi localities, in the northern part of the Medobory Hills, the bryozoans in a fine calcareous sand facies construct very well-preserved, encrusting as well as branching colonies, which are restricted to a few species dominated by the cyclostomes of Tubulipora flabellaris (Fabricius), T. dimidiata (Reuss), and unidentified tubuliporines (Taylor et al., 2006). Cheilostomes, such as common small nodules or celleporiform masses, either round-shaped or hemispherical, of multilamellar morphotype with encrusting bases of Celleporina medoborensis sp. nov. (see Figs. 4-6), are accompanied by common encrusting Schizoporella tetragona (Reuss), and Cryptosula terebrata (Sinzov), in the marly-silty facies and fine-grained calcareous sands or limestones.

The Miocene Celleporina occurrences from the Central Paratethys have been described mainly from the Badenian (see Bobies, 1956; Małecki, 1958; Pouyet, 1973; Alexandrowicz and Małecki, 1977), however, a new fossil record of C. medoborensis sp. nov. from the Medobory Hills (Ukraine) adds a new element to the rare Sarmatian fauna, to accompany the earlier erected $C$. dubovensis Zágoršek, from the Slovakian Danube Basin (Zágoršek, 2007).

\section{GEOLOGICAL SETTING}

The Miocene Medobory reefs form a zone a few km-wide and ca. $300 \mathrm{~km}$-long that extends NW-SE from the north of Ternopil in Ukraine across the Ukrainian-Moldovan border (south of Kamianets Podilskyi) to the Moldovan-Romanian border (Fig. 1). The Miocene sequence of Medobory consists of marine Upper Badenian and semi-marine Lower Sarmatian (Volhynian) deposits (Fig. 2; Jasionowski, 2006; Studencka and Jasionowski, 2011; Górka et al., 2012). Multispecific crustose coralline algae accompanied by hermatypic corals (Porites, Tarbellastraea), and vermetid gastropods are the most prominent components of the Badenian reef framework (Korolyuk, 1952; Janakevich, 1977; Jasionowski et al., 2006; Górka et al., 2012). The reefs were inhabited by a rich normal-marine biota consisting of bivalves and gastropods, echinoids, crustaceans, foraminifers and bryozoans (Studencka and Jasionowski, 2011; Górka et al., 2012). Bioclastic, marly and rhodolith facies occur in association with the reefs.

The Sarmatian buildups, known as serpulid-microbialite reefs, cover the slopes of the Badenian reefs, and form individual mounds called "toutra" (Fig. 2). They are composed mainly of calcite precipitates of microbial and inorganic origin, with a minor skeletal framework of serpulid tubes and, in places, bryozoans (Jasionowski, 2006). Locally, serpulid-microbialite boundstone is encrusted by thin crusts of coralline algae, probably of the genus Titanoderma Nägli et Cramer, 1852, bryozoans and sessile nubecularid foraminifers. The reef-dwelling biota is taxonomically very impoverished but often rich in individuals, and comprises a few species of bivalves (almost exclusively cockles of the genus Cerastoderma and less frequently mytilids), gastropods, foraminifers (elphidiids, miliolids), and ostracods typical of a restricted semi-marine environment (Studencka and Jasionowski, 2011; Górka et al., 2012; Peryt and Jasionowski, 2012).

The bryozoans studied were found in the lowermost portions of the Sarmatian reefs directly above the Badenian-Sarmatian contact (Fig. 3). Sarmatian organodetrital, slightly marly sands containing the bryozoans, together with an accompanying macro- and microfauna, occur in small pockets or depressions within the Upper Badenian reef limestone (Fig. 3A-E). The samples were collected from the calcareous sands that infilled small depressions in the top of the Badenian coralline algal reef (Figs. 2 and 3; cf. Peryt and Jasionowski, 2012).

In the Polupanivka sample, bryozoans co-occur with a monospecific assemblage of elphidiids comprising 10 species dominated by Elphidium aculeatum but also containing the diagnostic Sarmatian species E. reginum and E. koberi (Peryt and Jasionowski, 2012), demonstrating the Sarmatian age (see also Gedl and Peryt, 2011).

\section{MATERIAL AND METHODS}

The rich bryozoan material consisting of over 450 colonies of Celleporina medoborensis sp. nov. examined in this study, was collected during a few field seasons in the years 2001-2003 and 2007-2008 in the Polupanivka Quarry, and in 2010-2011 in the neighbouring Ditkivtsi Quarry (see Fig. 1) in the northern part of the Medobory Hills (western Ukraine; Fig. 2). The bryozoan fauna recognized in the Lower Sarmatian (Volhynian) serpulid-microbialite buildups shows a very patchy distribution among the reefs, and is mostly confined to the loose or weakly-cemented organodetrital or marly deposits. The sites at Polupanivka and Ditkivtsi yield the richest bryozoan fauna, among the known Medobory Sarmatian bryozoan-bearing localities, spread over a distance of ca. $150 \mathrm{~km}$ from Ternopil to Kamianets Podilskyi.

The weakly-cemented and partly loose deposits were washed and then sieved using a 0.1 to $0.5 \mathrm{~mm}$ diameter meshes, as well as larger sized meshes of 0.75 to $1.5 \mathrm{~mm}$. Selected specimens were cleaned ultrasonically and dried. Measurements were made using an eyepiece micrometer affixed to a Wild M10 microscope.

Well-preserved colonies were mounted using adhesive carbon tab backings onto standard SEM stubs and examined coated using a LEO 1430 scanning electron microscope at the Polish Geological Institute - National Research Institute. Scanned specimens are illustrated in Figures 4-6 and deposited in the collections of the Polish Geological Institute - National Research Institute, Warsaw (abbreviated MUZ PIG). One thin-section of a bryozoan colony cut longitudinally with respect to growth direction was produced to examine the internal structure (see Fig. 6E, F).

\section{SYSTEMATICS}

The newly erected species was compared with the other Celleporina species, mostly those recorded from the Carpathian 


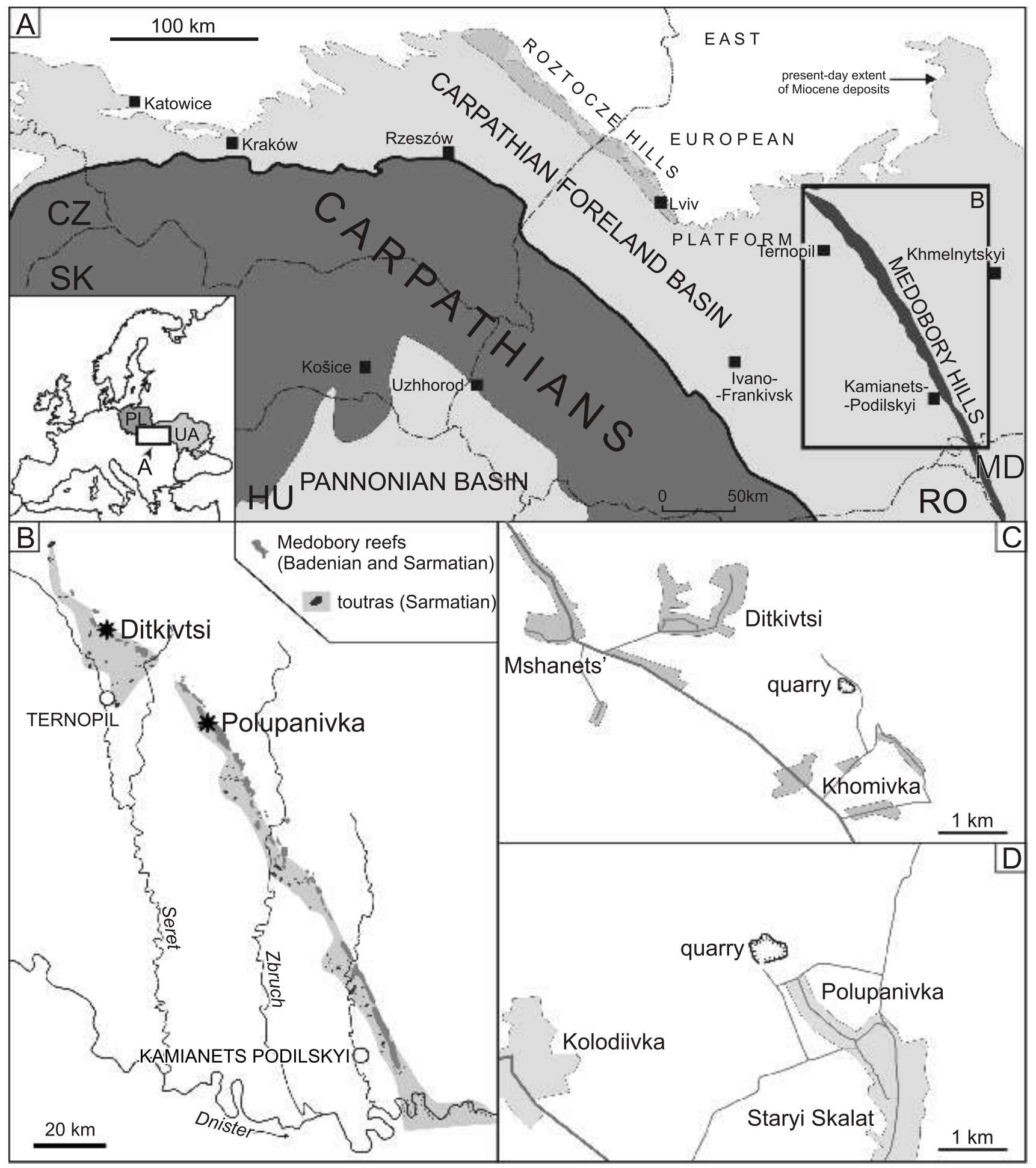

Fig. 1A - map of the Middle Miocene deposits in the Carpathian Foredeep Basin of Poland and Ukraine, showing the distribution of reef deposits (solid shading); B - distribution of the Badenian and Sarmatian reefs of the Medobory Hills (after Korolyuk, 1952; modified); C, D - detailed locations of the Polupanivka $\left(49.486^{\circ} \mathrm{N}, 2^{25.958}{ }^{\circ} \mathrm{E}\right)$ and Ditkivtsi $\left(49.734^{\circ} \mathrm{N}, 25.539^{\circ} \mathrm{E}\right) \mathrm{quarries}$

Foredeep such as C. rostrata (Małecki) described from the Upper Badenian fossiliferous clays and silts of the Gliwice Formation of southern Poland (see Małecki, 1958, p.182-184, rys. 5, tabl. XXII, fig. 2) as well as with the Lower Sarmatian C. dubovensis Zágoršek of the Danube basin, western Slovakia (see Zágoršek, 2007). The revision of the celleporids made by Pouyet (1973), who examined the material described by Małecki as Schismopora rostrata, transferred this species to Celleporina Gray on the basis of the morphology of the ovicell (Pouyet, 1973), a very important diagnostic feature which clearly outlines the affinity or differences of the materials examined (see also Pouyet, 1973, p. 118; Berning, 2006, p. 116).

The holotype and the paratypes of the newly erected species of Celleporina medoborensis sp. nov. from the Lower 


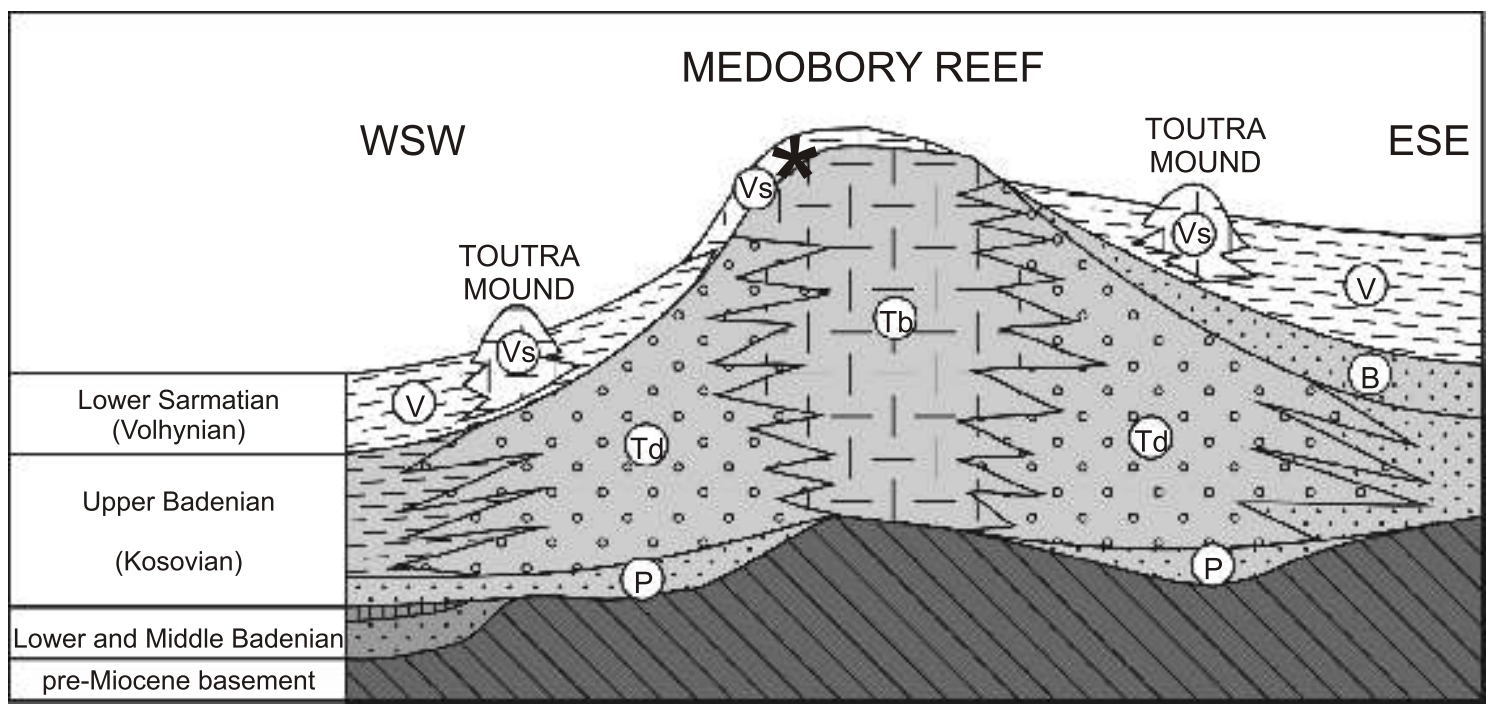

Fig. 2. Schematic geological cross-section through Medobory with approximate locations of the Lower Sarmatian (Volhynian) bryozoan-bearing sites studied (asterisk)

P - Pidhirtsi Beds (sands), Tb - Ternopil Beds (reef facies), Td - Ternopil Beds (organodetrital facies), B - Vyshhorodok Beds and Buhliv Beds (sands), V - Volhyn Beds including Sarmatian serpulid-microbialite reefs (Vs) (after Górka et al.., 2012)

Sarmatian (Volhynian) have been based on material collected in the Polupanivka Quarry of the Modobory Hills, which is the type locality (Figs. 4 and 5). The other specimens examined from Ditkivtsi Quarry are included to the same species of C. medoborensis on the base of the same morphological and morphometrical features (Fig. 6B-F).

Order CHEILOSTOMATA Busk, 1852

Suborder ASCOPORINA Levinsen, 1909

Infraorder LEPRALIOMORPHA Gordon, 1989

Superfamily CELLEPOROIDEA Johnston, 1882

Family CELLEPORIDAE Johnston, 1838

Genus Celleporina Gray, 1848

Type species: Lepralia hassallii Johnston, 1847

Celleporina medoborensis sp. nov. (Figs. 4-6)

Holotype: Specimen number MUZ PIG 1696.II.39, from the Polupanivka Quarry of the Medobory Hills - Figure 4A-D.

Paratype 1: Specimen number MUZ PIG 1696.II.23, from the Polupanivka Quarry of the Medobory Hills - Figure 5A, D, F.

Paratype 2: Specimen number MUZ PIG 1696.II.22, from the Polupanivka Quarry - Figure 5B, C, E.

Other material studied among the 403 colonies collected includes: Polupanivka Quarry: MUZ PIG 1696.II.25, and PIG 1696.II.40; as well as thirteen colonies numbered 1696.II.26-38, from Ditkivtsi Quarry (illustrated material). There are numerous colonies under the numbers of 1696.II.41-429 from Ditkivtsi Quarry.

Type horizon: Medobory reefs; Lower Sarmatian (Volhynian)

Type locality: Polupanivka, quarry near Ternopil, western Ukraine.

Derivation of the name: referring to the name of Medobory Hill.

D i a g n o s i s. - Colony encrusting, multilamellar, autozooecia large, bottle-shaped to circular, chaotically arranged with a few marginal pores; primary orifice with very broad, shallow U-shaped sinus without condyles and a wide rim in the proximal part; suboral avicularium oval-shaped, with a pivotal-bar, umbonate, raised, placed medially, single or rarely paired. Vicarious avicularia of varying size, differently oriented, parallel-sided. Ovicell hyperstomial, large, with a perforated tabula composed of ribs which vary in shape from subcircular, oval or triangular.

O c c u r r e n e. - Lower Sarmatian (Volhynian), Polupanivka and Ditkivtsi quarries, Medobory Hills, western Ukraine (Central Paratethys).

M e a s u re ments. - Size of the colony (max.) $7 \times 11 \mathrm{~mm}$, size of the colony (min.) $-2 \times 2 \mathrm{~mm}$; height of the colony (max) - $11 \mathrm{~mm}$, diameter of the colony (max) - $11 \mathrm{~mm}$; autozooecial frontal wall length $0.37-0.60 \mathrm{~mm}$, autozooecial frontal wall length on the basal side 0.24 (min.) to $0.30 \mathrm{~mm}$, frontal wall width (proximal) $0.22-0.30 \mathrm{~mm}$; length of the orifice $0.10-0.12 \mathrm{~mm}$, width of the orifice $0.10-0.15 \mathrm{~mm}$; length of the vicarious avicularia $0.22-0.35 \mathrm{~mm}$, width of the vicarious avicularia $0.15-0.17 \mathrm{~mm}$, width of the adventitious (suboral) avicularia $0.07-0.09 \mathrm{~mm}$, length of the adventitious avicularia $0.07-0.12 \mathrm{~mm}$; width of the ovicell $0.22-0.33 \mathrm{~mm}$, length of the ovicell $0.14-0.21 \mathrm{~mm}$; width of the ovicell window $0.15-0.24 \mathrm{~mm}$, height of the ovicell window $0.07-0.15 \mathrm{~mm}$.

D e s c r i p i o n. - Colony encrusting multilamellar, with hemispherical (Fig. 5A), globular (Figs. 4A, 5B and 6A, C), irregular spherical or dome-shaped forms (Fig. 6B), some with a broadly encrusting base, also often with a hollow cylindrical canal ranging in diameter from 1 to $4 \mathrm{~mm}$ (Fig. 6E), placed in the basal part of a colony; some of colonies penetrated by a subcircular hole of max. width of $2.6 \mathrm{~mm}$ (Fig. 6B). Autozooecia bottle-shaped, suberect, separated by slightly raised marginal boundaries; (Figs. 4B-E, 5C, E and 6D), variously orientated on the uneven colony surface (Figs. 4A-E, 5C, E and 6D), but in some places predominant direction to the growing edge is seen (Fig. 4B). The shorter autozooecia occur usually on the basal side of a colony; they are often erect and circular. Frontal wall 

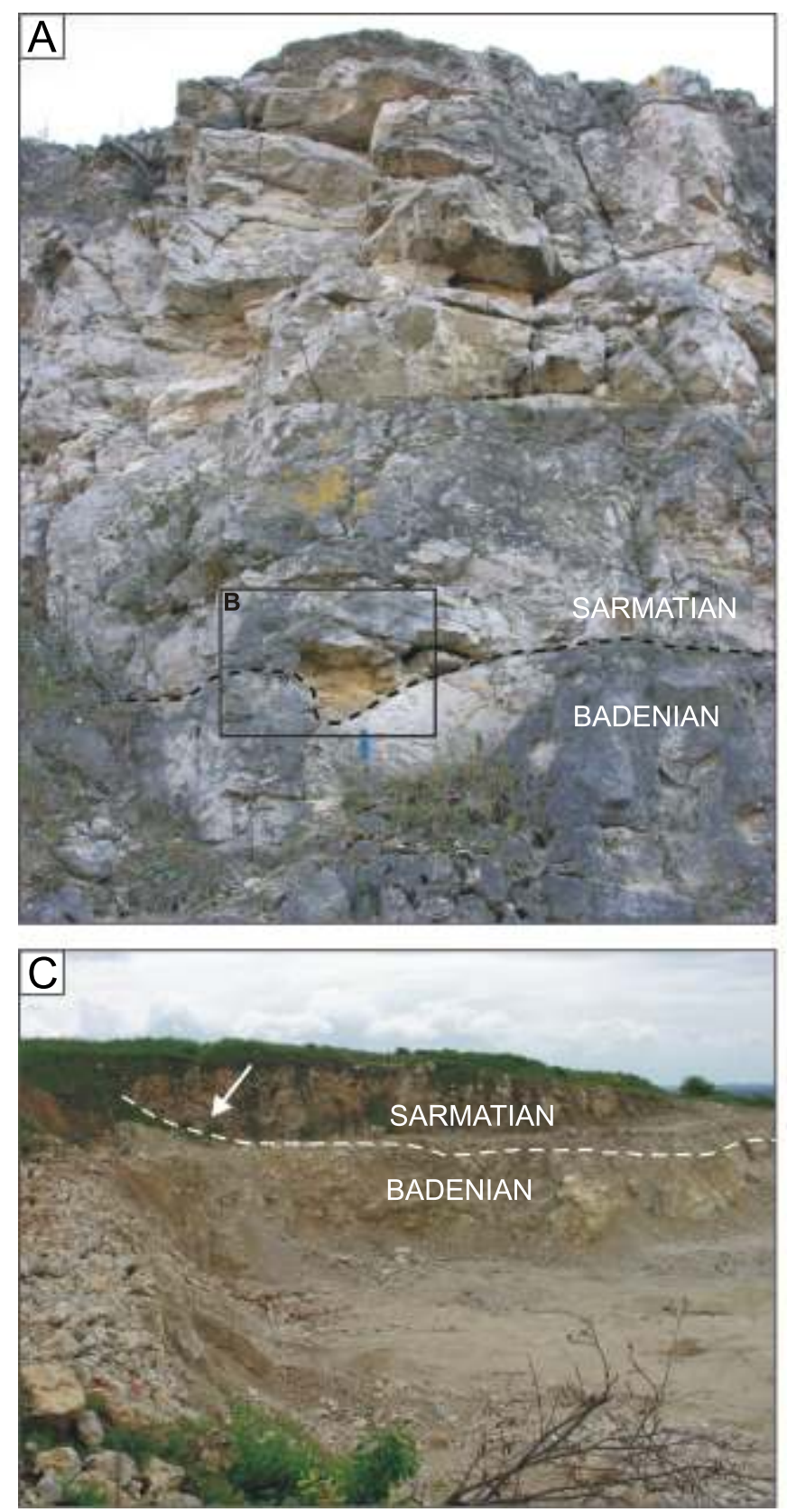
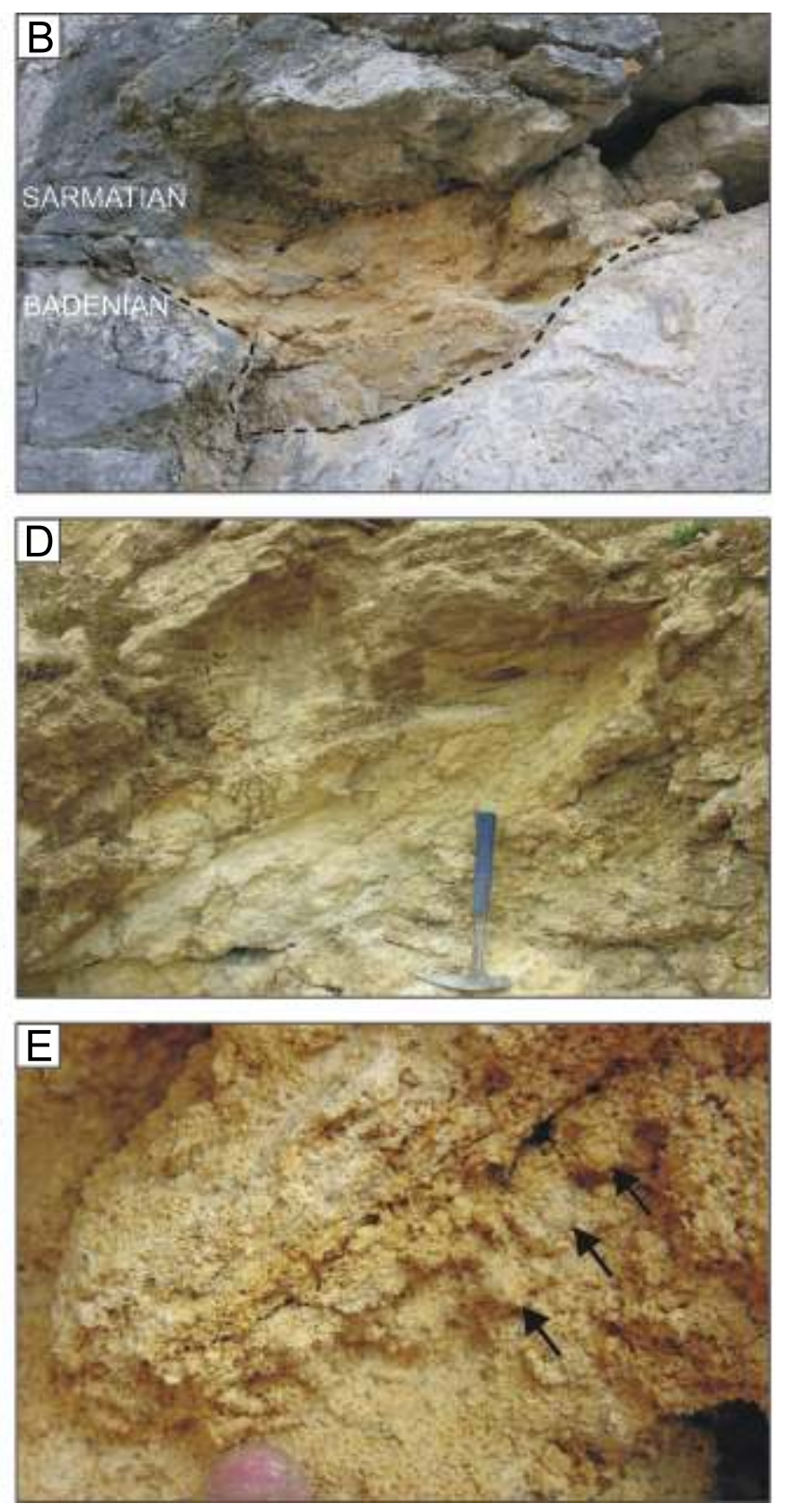

Fig. 3A, B - pocket in the top of the Badenian reef in Polupanivka filled with Sarmatian calcareous sands; C - view of the south face of Ditkivtsi Quarry showing precise location of the bryozoan-bearing deposits (arrowed - D, E); D, E - organodetrital sands with bryozoan colonies: E - large hemispherical colonies of Celleporina medoborensis sp. nov., arrowed

convex, smooth, slightly distally raised towards peristome (Figs. 4C, D and 5C), usually surrounded by a few areolar, marginal pores which vary in number from $2-3$ (min.) to 5 (max.) on each side of the zooecium (Figs. 4B, E, 5E and 6D), sometimes they are barely seen (Fig. 4D). Primary orifice deeply set, slightly wider than long, with a very broad, shallow U-shaped sinus, of depth of one-third of maximum orifice width; bordered by a wide rim in the proximal part of the orifice (Fig. 4F) and enclosed by a tubular narrow peristome (Figs. 4C, E, F, 5C, E and 6D); in a very few autozooecia around the peristome there are small insertions or tubercules (see also Morris, 1979, p. 486), (Figs. 4B, E and 5C, E) which occur rarely and irregularly; condyles lacking (Fig. 4F). Avicularia of two types: adventitious and vicarious. Adventitious avicularia are suboral, common in ovicellate autozooecia, but also occur in non-ovicellate ones; the proximal peristome margin is raised to form a suboral umbo, projecting or raised, bearing a roughly oval-shaped avicularium on its top with a pivotal bar, situated proximally to the orifice (Figs. 4B-E, 5C, E and 6D); very rarely paired (Figs. 4D and 5C, E). Vicarious avicularia common, of varying size, from large ones to tiny, of size of $0.1 \times 0.05 \mathrm{~mm}$ or smaller; spatulate and usually with parallel lateral edges, rostrum pointing distolaterally, proximolaterally or perpendicular in relation to the nearest autozooids (Figs. 4C, D, 5C-F and 6D), pivotal bar complete without columella (Figs. 4C, D, 5D-F and 6D). Ovicells are hyperstomial, globular (Figs. 4B-D and 5C-F), with a perfo- 

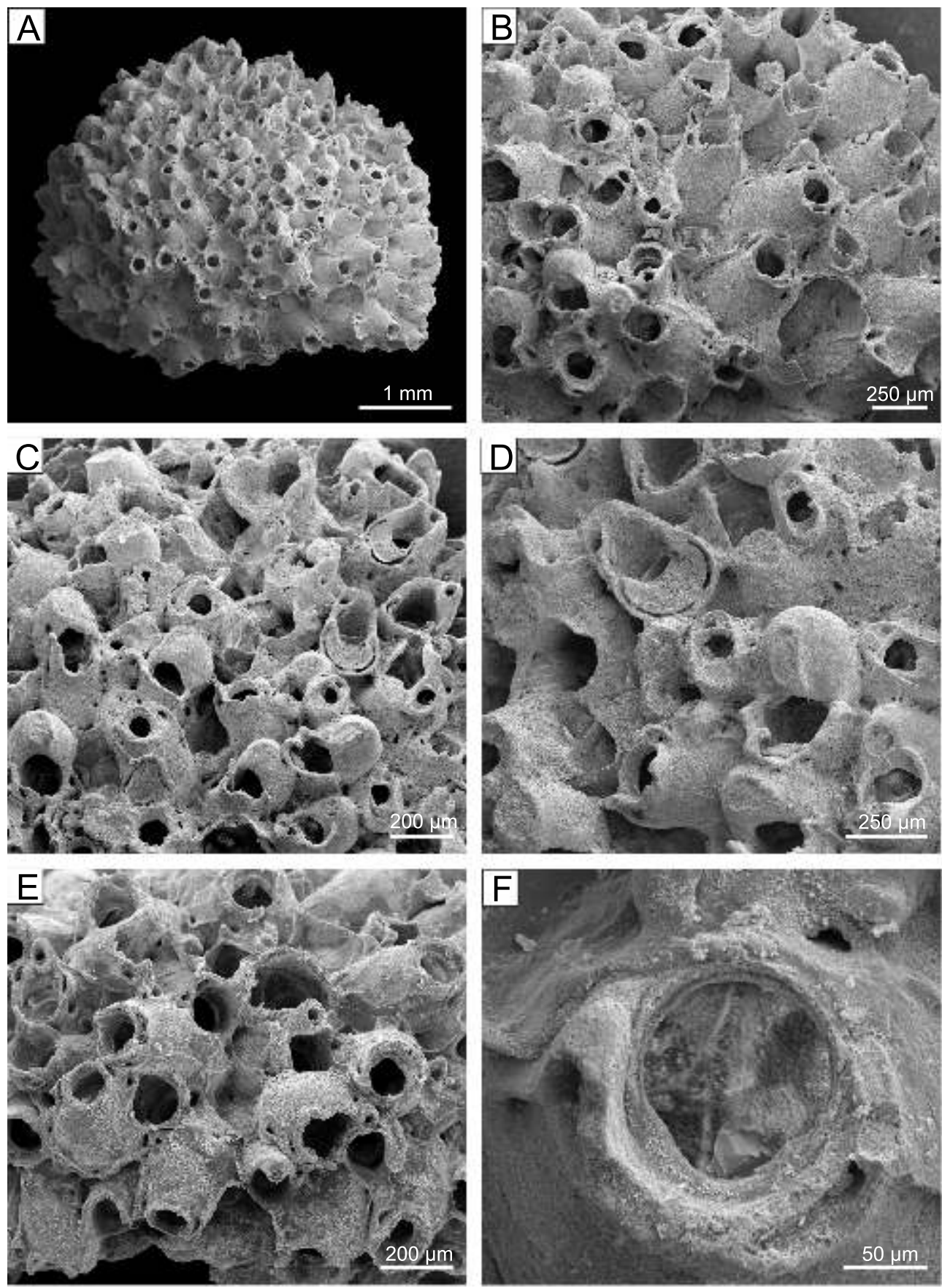

Fig. 4. Celleporina medoborensis sp. nov.

A - small globular colony showing ovicellate and non-ovicellate autozooecia; B - morphology of the zoarial surface of the same colony showing ovicellate and non-ovicellate autozooecia, suboral and vicarious avicularia (in the middle) as well as some autozooecia with small insertions in the distal part, around the peristome; $\mathbf{C}$ - part of the zoarial surface of the same colony showing ovicellate autozooecia showing an umbonate suboral avicularium, two spatulate avicularia, varying in size; $\mathbf{D}$ - group of autozooecia, some of them with a large globular, highly raised ovicell with the oval rib-like frontal area (tabula), a few spatulate avicularia of different sizes also seen; $\mathbf{E}$ - bottle-shaped, suberect autozooecia, with well-marked boundaries bearing a few areolar pores and a prominent umbonate single suboral avicularia; $\mathbf{F}$ - sinuate orifice of autozooecium showing a wide, shallow sinus without condyles; E, F - MUZ PIG 1696.II.40; A-D - holotype MUZ PIG 1696.II.39; A-F - Polupanivka Quarry 

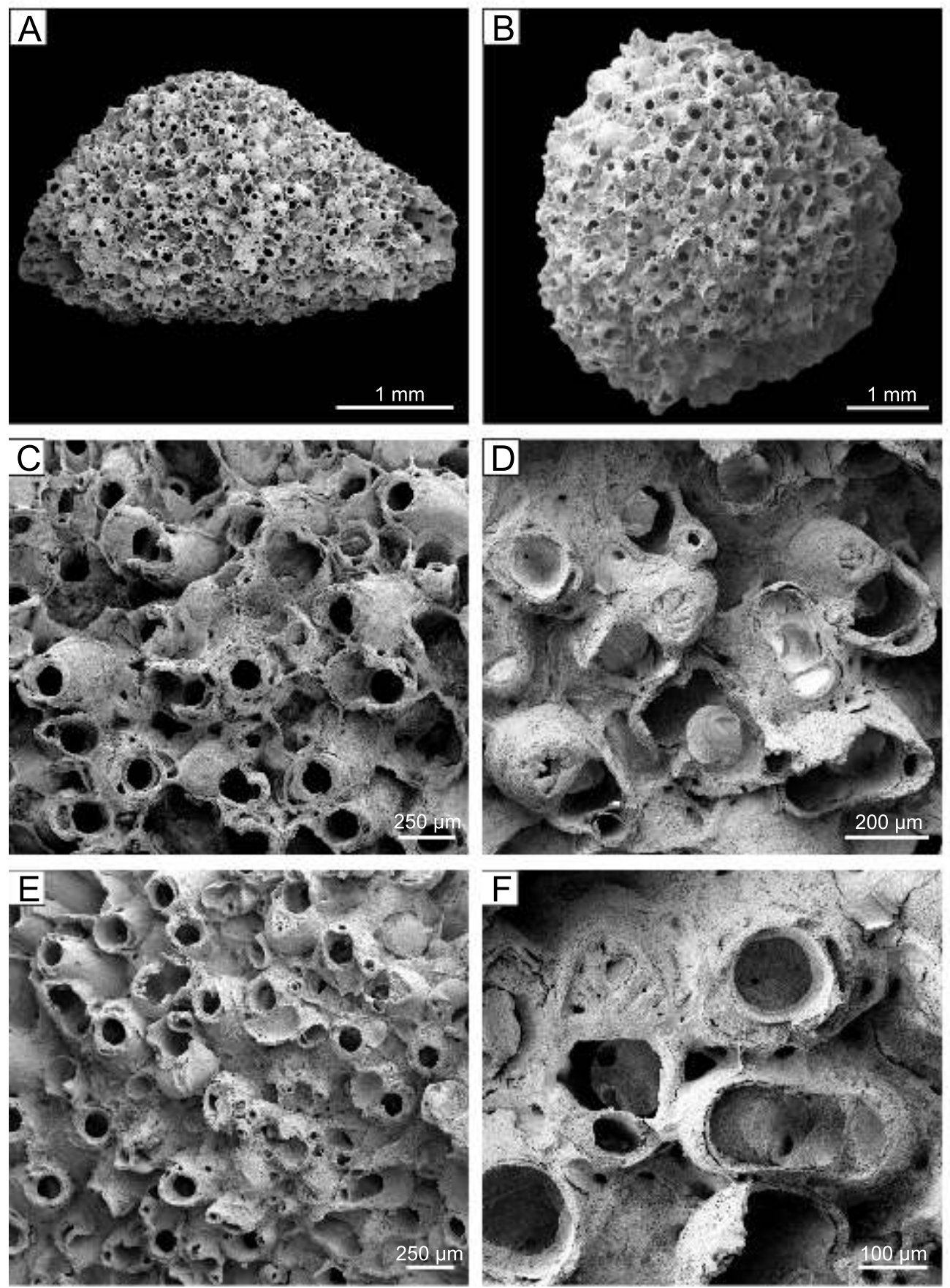

Fig. 5. Celleporina medoborensis sp. nov.

A - hemispherical colony of Celleporina medoborensis sp. nov. showing a chaotic accumulation of autozooecia; B round colony showing mostly ovicellate chaotically arranged autozooecia; $\mathbf{C}$ - external surface of colony showing ovicellate and non-ovicellate autozooecia and adventitious and vicarious avicularia randomly dispersed over the colony surface; D - group of ovicellate autozooecia showing the rib-like frontal area of the ovicell, a large vicarious avicularium (in the middle); $\mathbf{E}$ - morphology of the zoarial surface showing the ovicellate autozooecia with a triangular ribbed area and non-ovicellate autozooecia; vicarious avicularia, variable in size, also seen; $\mathbf{F}$ - ovicellate zooecium showing the hemispherical ribbed frontal area of the ovicell and a single, large spatulate avicularium with the pivotal bar and parallel lateral sides (in the middle); A, D, F- paratype 1, MUZ PIG 1696.II.23; B, C, E - paratype 2, MUZ PIG 1696.II.22; A-F - Polupanivka Quarry 

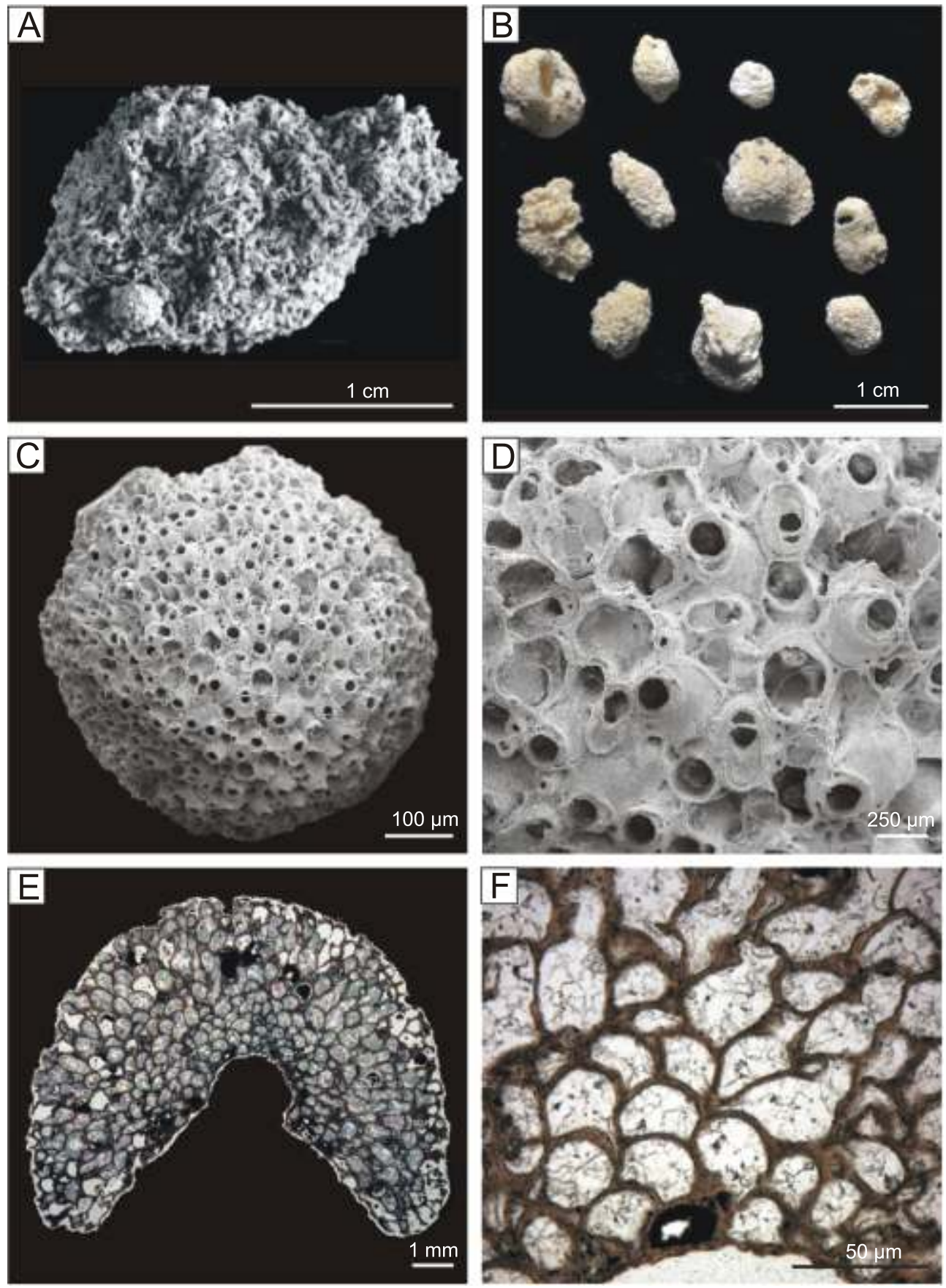

Fig. 6A - fragment of the serpulid-microbialite reef, composed of shelly detritus showing the differently-shaped bryozoan colonies, accompanied by molluses, gastropods, serpulids and foraminifers, MUZ PIG 1696.II.25, Polupanivka Quarry; B-F - Celleporina medoborensis sp. nov.

B - assemblage of differently-shaped colonies of Celleporina medoborensis sp. nov., MUZ PIG 1696.II.26-36; C - colony of Celleporina medoborensis sp. nov. showing the autoautozooecia and large vicarious avicularia; D SEM image showing the external morphology; C, D - MUZ PIG 1696.II.37; E - longitudinal thin-section showing the internal structure composed of accumulated autozooecia; F - autozooecia filled by calcitic cements; E, F MUZ PIG 1696.II.38; A - Polupanivka Quarry, B-F - Ditkivtsi Quarry 
rated, differently-shaped tabula (Figs. 4B-D and 5D-F) varying in shape from distinctly subcircular (Figs. 4B and 5D, F), or close to oval-shaped (Fig. 4B-D) to triangular (Fig. 5E). The frontal area (tabula), is covered by 7 to 11 radial ribs (Fig. 5D-F), of varied thickness, that may fuse (Figs. 4B-D and 5D-F). In some ovicellate autozooecia the ribs are not well seen, depending on the degree of calcification (Fig. 4D).

In thin-section the autozooecia are chaotically arranged to form the multilamellar colony (Fig. 6E). Diagenetic calcitic cements infill the autozooecial chambers (Fig. 6F).

R e m a r k s. - Pouyet (1973, p. 114-119) in her revision of the celleporids of the Neogene of the Rhone Basin stated that Celleporina Gray, 1848 is characterized by the presence of an ornamented ovicell, interzooecial avicularia as well as suboral or spatulate avicularia. The combination of features such as the possession of the hyperstomial ovicell, with a differently-shaped tabula varying from subcircular, closely oval to triangular in shape, with a 7 to 11 radial ribs on the frontal area; the numerous, size-variable vicarious, spatulate avicularia as well as the presence of a shallow, wide, U-shaped orificial sinus, the lack of condyles and the raised oval-shaped oral avicularium (single, rarely paired), are the main characteristics of this species (see Figs. 4-6). Specimens of Celleporina medoborensis sp. nov. described from the Lower Sarmatian of Ukraine occur as small, mound-like-shaped colonies, mostly multilamellar with a wider encrusting base, or possessing a subcircular hole in the distal part or a basal cylindrical canal (Fig. 6E), which suggests that the colonies apparently grew on ephemeral substrates (Fig. 6B).

The width and partly the length of the frontal wall, the width of the ovicell, the length of the vicarious avicularia as well as the possession on the frontal wall of 2-5 areolar pores agree with the characters given for $C$. rostrata by Małecki from the Silesian part of the Carphatian Foredeep (see Małecki, 1958, fig. 5, pl. XXII, fig. 2, p. 182-184). There are also differences in a few morphological features between $C$. medoborensis and $C$. rostrata such as the absence of the pivotal bar in the spatulate interzooecial avicularia, however, this feature does not occur regularly in $C$. rostrata (see Pouyet, 1973, p. 118). Moreover, $C$. rostrata possesses a larger number of radial ribs (12-17) in the tabula of the recumbent ovicell seen in the specimen illustrated in text-fig. 5 of Małecki (1958), however, the specimen illustrated on his pl. XXII, fig. 2 shows 8 to 9 ribs, similarly to the specimens from Ukraine which have 7 to 11 . The Polupanivka and Ditkivtsi specimens appear to have slightly smaller transverse orificial measurements as well as larger suboral avicularium, which is not so distantly positioned to the orifice as in C. rostrata: it is roughly oval-shaped with a pivotal bar in contrast to $C$. rostrata, where the suboral avicularium is round. Further differences between $C$. medoborensis sp. nov. and $C$. rostrata are that the frontal perforated area of the ovicell (tabula) in C. medoborensis sp. nov. shows variability in shape from subcircular, roughly oval to triangular, whereas in C. rostrata it is always subcircular (see Małecki, 1958, text-fig. 5, pl. XXII, fig. 2; cf. our Figs. 4C, D and 5E, F).

The length of the autozooecial frontal wall is similar in C. rostrata and C. medoborensis sp. nov.; however, this feature within the latter species shows variation, especially in the autozooecia that are situated in the basal part of the colony, which are mostly erect and show the smaller length of the frontal wall. Similarly, the width of the ovicell in C. medoborensis is often larger than in C. rostrata. The sizes of the vicarious avicularia in $C$. medoborensis are also very variable, ranging from very small to large (see Figs. 4C, D and 5E). The specimens assigned to $C$. medoborensis display a range of variability in a few morphological characters such as the number of the arealar pores, the number of ribs in the tabulae, and in the view of the marginal walls, which may be either inconspicuous or more prominent. All these features may be also produced by secondary calcification, which affects the zooidal frontal surface. Nevertheless, in view of the lack of the few morphological characters of $C$. rostrata given by Małecki (1958, p. 182-183) in his description and illustrations, especially owing to the details of the primary orifice such as the presence or absence of condyles, details of the oral adventitious and vicarious avicularia and their measurements, as well as the lack of information on the intraspecific variation of $C$. rostrata (Małecki), the specimens studied of $C$. medoborensis differ from $C$. rostrata in a number of the above-mentioned features. Because of the loss of the type material, the comparison between these both species is, however, only based on documentary material (see Małecki, 1958, p. 182-183; see also Pouyet, 1973, p. 118-119).

Celleporina miniscula described by Pouyet (1973, pl. 13, fig. 4; pl. 14, figs. 5, 6) from the Miocene of Austria is similar to the Ukrainian specimens studied in general aspects of the frontal wall and in having large spatulate avicularia; however, the sizes of the two latter features are smaller in C. minuscula Pouyet (1973, p. 117-118, pl. 14, figs. 5, 6). The suboral avicularium also has a deep triangular sinus in C. miniscula; vicarious avicularia in this species are rare.

Another Miocene species described from the Vienna Basin is Celleporina kalksburgensis (Bobies) (see Bobies, 1956, tafel VIII, fig. 20; Pouyet, 1973, pl. 19, figs. 1, 2) but this species shows distinctive features such as a large aperture without a sinus, which is surrounded by many pores, and the possession always of two adventitious oral avicularia which distinguishes it from C. medoborensis (see Figs. 4-6).

The recent description of Celleporina dubovaensis Zágoršek from the Sarmatian of the Danube Basin in Slovakia (Zágoršek, 2007, p. 299-303, figs. 2-6) shows specimens which differ from $C$. medoborensis sp. nov. in having smaller orifices, a shorter vicarious spatulate avicularium, a wider rostrum of the vicarious avicularium, and a larger number of areolar pores which vary from 4 to 9 . A very important feature which distinguishes both species is a detail of the vicarious avicularium in C. dubovaensis (see Zágoršek, 2007, p. 300, Fig. 4), which shows at its end one small, suboral avicularium. Another feature which distinctly differentiates $C$. dubovaensis from $C$. medoborensis is the morphology of the ovicell window which in $C$. dubovaensis is mostly subcircular, covered by a smaller number of ribs varying from 5 to 7 (Zágoršek, p. 301, Fig. 2, and p. 302, figs. 4 and 6); the width of the ovicell window is also more or less twice as small as in C. medoborensis, however, due to the variability in the shape of the tabula, this feature is not constant. Autozooecia from the lateral view of $C$. dubovensis, Zágoršek show suboral avicularia on the top of long peduncles, whereas in $C$. medoborensis and $C$. rostrata 
the proximal part of the zooecium is raised and umbonate bearing a suboral avicularium (cf. Zágoršek, 2007, p. 302, fig. 5, and our Figs. 4-6). The morphology of the ovicell of the Ukrainian, Upper Silesian, and Slovakian specimens of Celleporina generally shows some similarity in architecture, but they differ in a number of morphological and morphometric features, as well as in the possession of a different number of ribs in the tabula (see Małecki, 1958, tabl. XXII, fig. 2; Zágoršek, 2007, p. 302; Figs. 4 and 6); however, the diagenetic processes may have influenced the appearance of some morphological characters (such as the number of areolar pores, and ribs which may fuse; therefore, these characters are not always apparent).

\section{DISCUSSION}

Celleporina in Europe ranges back to the Eocene and biogeographical data suggests that this genus is autochthonous to Europe (Morris, 1979). A more extensive occurrence of Celleporina was reported from the Miocene of the Central Paratethys (Bobies, 1957; Małecki, 1958; Fordinal et al., 2006, Zágoršek, 2007), including the present description of C. medoborensis sp. nov. from its northeastern part, but it has been recorded also in the Mediterranean area of France, Morocco and Algeria (see Canu and Lecointre, 1930; Moissette, 1993). Apart from these European and North African occurrences, Celleporina has been described from the Miocene of SE Australia and New Zealand (Canu and Bassler, 1935; Brown, 1952; Gordon, 2009). A large number of species are known from Recent temperate and Arctic waters (see Kluge, 1929).

The Lower Sarmatian Medobory assemblage studied consists entirely of small, delicate colonies of tubuliporinids, crisiids and encrusting sheet-like schizoporelloids (Schizoporella and Cryptosula), and it includes very common, typically mound-like (either spherical or hemispherical; Figs. 4-6), mostly multilamellar colonies of Celleporina medoborensis sp. nov. The presence of the axial canals placed centrally or laterally and seen in the distal part of the colony (Fig. 6B), as well as often oriented horizontally to the substrate in its basal part (Fig. 6E), is probably a result of encrustation on a cylindrical substrate which was soft and did not fossilize (see also Moissette and Pouyet, 1991). Some of the colonies, particularly those from Polupanivka, are regular and round in shape (Figs. 4A, B, 5A and 6C) with a broad encrusting concave basal part adapted for fixation to soft or hard substrata, however, no informative bioimmurations of the perished substrates are present on the basal laminae of the bryozoans. Most specimens of C. medoborensis from Ditkivtsi Quarry (Fig. 6B-D) form round but also irregular colonies with the presence of axial canals similar in size to the diameter of the cylindrical stems ranging in width from $0.4-2.6 \mathrm{~mm}$, inferred to have grown attached to the algal filaments (see Małecki, 1970, 1974). The presence of a narrow axial canal running from a base to the top of a colony suggests that the colonies encrusted the thallus or cylindrical stems of algae, described from the Sarmatian, possibly of the Chlorophyta (Acicularia, Neomeris, Cympolia, Acetabularia) occurring abundantly in Miocene strata of different regions of the Paratethys (Pokorny, 1948, Małecki, 1970, 1974; Stancu and Tatou, 1974; see also Paruch-
Kulczycka, 1994; Jasionowski et al., 2004; Zágoršek, 2007). The rich Chlorophyta algal assemblage described from the Lower Sarmatian of the silty and sandy facies of the Polish Central Paratethys basin indicates that its occurrence was connected with a warm, shallow, lagoonal environment of decreased salinity (see Małecki, 1970; Jasionowski et al., 2004).

Recent bryozoans can grow around cylindrical substrates of both plant and animal origin (see Hara and Taylor, 1996). Bone and James (1993) figured several different species of bryozoan attached to cylindrical stems of sea-grasses from shallow-water environments of the Lacepede Shelf, southern Australia.

The relationship between the pattern of sedimentation and the bryozoan colony form can be a tool in the reconstruction of environmental settings (Reguant et al., 1991). The abundant accumulation of nodular, celleporiform $C$. medoborensis colonies in the fine-grained organodetrital deposits of the Polupanivka and Ditkivtsi quarries may indicate deposition in a shallow-water environment of a rather low energy regime within the photic zone (cf. Stach, 1936; Pouyet, 1973; Reguent and Zamarreño, 1987; see also Peryt and Jasionowski, 2012).

The bryozoan assemblage of Polupanivka and Ditkivtsi, which contains the euryhaline taxa, may indicate environmental changes, i.e. a decrease in water salinity in the Paratethys at the onset of the Early Sarmatian (see also Studencka and Jasionowski, 2011). On the other hand, at Polupanivka a monospecific shallow-marine foraminiferal assemblage is composed exclusively of various elphidiid species that seem to indicate elevated salinity (Peryt and Jasionowski, 2012). This may, though, be an apparent inconsistency caused by local evaporation of generally semi-marine water of the Sarmatian Paratethys characterized by decreased salinity and elevated alkalinity (see Jasionowski, 2006; Studencka and Jasionowski, 2011). Similar abnormal palaeoenvironmental conditions with fluctuating salinities and calcium carbonate supersaturation prevailed also in other Sarmatian Paratethys basins such as the Zsámbék Basin in Hungary (Cornée et al., 2009; Tóth et al., 2010).

It should be added that a recently studied bryozoan assemblage composed of normal-marine regime taxa such as Beania magellanica, B. mirabilis, Diplosolen obelia, along with Celleporina tubulosa and others was recorded as brackish water species growing on rocks inside the centre of submarine spring outlets (Novosel et al., 2005).

\section{CONCLUSIONS}

The Sarmatian bryozoan fauna documented from the fine-grained calcareous sands in the Polupanivka and Ditkivtsi quarries of the Medobory Hills (western Ukraine) consists entirely of small and delicate colonies, mostly of membraniporiform and celleporiform growth-forms. A considerable number of specimens found at Medobory belong to the distinctive mound-like, roughly globular colonies of the species of $C$. medoborensis, described here, which adds new data to the distributional pattern of this genus in the Early Sarmatian (Volhynian).

The bryozoan biota studied underlines its potential for reconstruction of the palaeoenvironmental setting of the Medobory carbonate buildups, such as the dominance of soft 
substrates, a calm hydrodynamic regime and marine parameters such as fluctuating salinities during the Middle Miocene (see Jasionowski, 2006).

The axial canal present in the majority of colonies of C. medoborensis sp. nov., particularly those from Ditkivtsi Quarry (Fig. 6B), indicates that these organisms lived mostly as epiphytes attached to a cylindrical substratum, possibly dasycladaceans, which have been described from Lower Sarmatian strata of the Central Paratethys (see Pokorny, 1948; Małecki, 1970, 1974; Stancu and Tatou, 1974; Zágoršek, 2007; see also Alexandrowicz, 1997). Similarly, colonies of Tubulipora Lamarck from the same assemblage show the presence of a narrow basal canal indicating possible fixation to algal stem.
Acknowledgements. Gratitude is extended to Prof. Dr. N. Vávra, for helpful discussion concerning the Sarmatian bryozoan fauna of the Central Paratethys area. We are greatly indebted to L. Giro for providing SEM assistance, as well as to Ms. B. Ruszkiewicz for taking the macrophotographs. Thin-sections were prepared by Mr. A. Szumny. We wish to thank to the Polish Ministry of the High Education and the Science for the financial support of this study under projects N307 041 32/1901 and N307 113635. The authors extend kindest thanks to the reviewers of this paper: Dr. B. Berning, Dr. P. D. Taylor, Prof. Dr. N. Vávra and Dr. K. Zágoršek for their comments, remarks and suggestions.

\section{REFERENCES}

ALEXANDROWICZ S.W. (1997) - Lithostratigraphy of the Miocene deposits in the Gliwice area (Upper Silesia, Poland). Bull. Pol. Acad. Sc., 45 (2-4): 167-179.

ALEXANDROWICZ S.W. and MAŁECKI J. (1977) - Bryozoan assemblage in the Miocene marine sediments of Southern Poland. Bull. Pol. Acad. Sc., Ser. Sc. Terre, 25 (1): 47-56.

ANDRUSOV N. (1899) - Die südrussischen Neogenablagerungen 2-ter Theil. Die Verbreitung und die Gliederung der sarmatischen Stufe. Verh. Russ. Mineral. Ges., 36: 101-170.

ANDRUSOV N. (1902) - Die südrussischen Neogenablagerungen III: Sarmatische Stufe. Verh. Russ. Mineral. Ges., 39: 337-493.

BAGDASARYAN K.G. and PONOMARIEVA L.D. (1982) - About the place of the Bryozoa in the ecosystems of Sarmatian Seas (in Russian with English summary). Paleont. Sb., 19: 76-81.

BERNING B. (2006) - The cheilostome bryozoans fauna from the Late Miocene of Niebla (Guadalaquivir Basin, SW Spain): environmental and biogeographic implications. Mitt. Geol.-Paläont. Inst. Univ. Hamburg, 90: 7-156.

BONE Y. and JAMES N.P. (1993) - Bryozoans as carbonate sediment producers on the cool-water Lacepode Shelf, southern Australia. Sedim. Geol., 86: 247-271.

BOBIES C.A. (1956) - Die Bryozoanfauna der tortonen Strandbildnugen von Kalksburg, bei Wien. Jb. Geol. Bundesanst., 99: 225-258.

BOBIES C.A. (1957) - Bryozoenstudien II. Die Bryozoen des österreichischen Sarmats. Jb. Geol. Bundesanst., 100: 81-114.

BROWN D.A. (1952) - Tertiary cheilostomatous Polyzoa of New Zealand. Monogr. Brit. Mus. (Nat. Hist.), London.

CANU F. and BASSLER R.S. (1935) - New species of Tertiary cheilostome Bryozoa from Victoria, Australia. Smithson. Misc. Collns., 93: 1-54.

CANU F. and LECOINTRE G. (1930) - Les Bryozoaires Cheilostomes des faluns de Touraine et d'Anjou. Mem. Soc. Geol. Fr., N.S., 4: 83-130.

CORNÉE J.J., MOISSETTE P., SAINT MARTIN J.P., KÁZMÉR M., TÓTH E., GÖRÖG A., DULAI A. and MÜLLER P. (2009) - Marine carbonate systems in the Sarmatian (Middle Miocene) of the Central Paratethys: the Zsambek Basin of Hungary. Sedimentology, 56: 1728-1750.

FORDINAL K., ZÁGORŠEK K. and ZLINSKÁ A. (2006) - Early Sarmatian biota in the northern part of the Danube Basin (Slovakia). Geol. Carpath., 57: 123-130.

GEDL P. and PERYT D. (2011) - Dinoflagellate cyst, palynofacies and foraminiferal records of environmental changes related to the Late Badenian (Middle Miocene) transgression at Kudryntsi (western Ukraine). Ann. Soc. Geol. Pol., 81 (3): 331-339.

GHIURCA V. (1968) - Le biotope récifal à bryozoaires du Miocène de la Roumanie. Atti Soc. It. Sc. Nat. Mus. Civ. St. Nat. Milano, 108: $165-173$.
GHIURCA V. and STANCU J. (1974) - Les Bryozoaires sarmatiens du Paratéthys Central. In: Chronostratigraphie und Neostratotypen (eds. A. Papp, F. Marinescu and J. Senes). Miozän der Zentralen Paratethys. M5 Sarmatien der Slowak. Akad. Wissensch., 4: 298-317.

GORDON P.D. (2009) - New bryozoan taxa from a new marine conservation area in New Zealand, with a checklist of Bryozoa from Greater Cook Strait. Zootaxa, 1987: 39-60.

GÓRKA M., STUDENCKA B., JASIONOWSKI M., HARA U., WYSOCKA A. and POBEREZHSKYY A. (2012) - The Medobory Hills (Ukraine). Middle Miocene reef systems in the Paratethys: their biological diversity and litofacies. Biul. Państw. Inst. Geol., 449: $147-174$.

HARA U. and TAYLOR P.D. (1996) - Jurassic bryozoans from Bałtów (Holy Cross Mts., Poland). Bull. Nat. Hist. Mus. Geol., 52 (1-2): 91-102.

HARZHAUSER M. and PILLER W.E. (2007) - Benchmark data of a changing sea - palaeogeography, palaeobiogeography, and events in the Central Paratethys during the Miocene. Palaeogeogr. Palaeoclimatol. Palaeoecol., 253: 8-31.

HILBER V. (1882) - Geologische Studien in den ostgalizischen Miocän-Gebieten. Jb. K.-K. Geol. R.-A., 32 (2): 194-323.

JANAKEVICH N. (1977) - Middle Miocene reefs of Moldavia (in Russian). Shtiintsa Publishers, Kishinev.

JASIONOWSKI M. (2006) - Facies and geochemistry of Lower Sarmatian reefs along the northern margin of the Paratethys in Roztocze (Poland) and Medobory (Ukraine) region: paleoenvironmental implications (in Polish with English summary). Prz. Geol., 54 (5): 445-454.

JASIONOWSKI M., PERYT T.M. and CZAPOWSKI G. (2004) - Neogen (miocen). In: Budowa geologiczna Polski, I. Stratygrafia, cz. 3a. Kenozoik. Paleogen. Neogen (eds. T.M. Peryt and M. Piwocki): 213-224. Państw. Inst. Geol.

JASIONOWSKI M., GÓRKA M., STUDENCKA B. and POBEREZHSKYY A. (2006) - Miocene of Medobory Hills (Podillya, west Ukraine) (in Polish with English summary). In: Przebieg i zmienność sedymentacji w basenach przedgórskich (eds. A. Wysocka and M. Jasionowski): 25-27. II Polska Konferencja Sedymentologiczna POKOS2, 20-23.06.2006 r., Zwierzyniec.

KLUGE H. (1929) - Die Bryozoen des sibirischen Eismeers. Rab. Murm. Biol. St., 3: $1-33$.

KOROLYUK I.K. (1952) - Podolskiye toltry i uslovia ikh obrazovanya. Trudy Inst. Geol. Nauk. Akad. Nauk SSSR, 56: 1-138.

MAŁECKI J. (1958) - Mszywioły tortońskie z Gliwic Starych. Rocz. Pol. Tow. Geol., 28 (2): 169-194.

MAŁECKI J. (1970) - Chlorophyta from Miocene sediments of Poland (in Polish with English summary). Rocz. Pol. Tow. Geol., 40: 167-176.

MAŁECKI J. (1974) - Grünalagen Chlorophyta aus den sarmatischen Ablagerungen von Gliwice Stare (Polen). In: Chronostratigraphie und 
Neostratotypen (eds. A. Papp, F. Marinescu and J. Senes). Miozän der Zentralen Paratethys. M5 Sarmatien der Slowak. Akad. Wissensch., 4: 598-605.

MOISSETTE P. (1993) - Bryozoan assemblages in Messinian deposits of western Algeria. Lethaia, 26: 247-259.

MOISSETTE P. and POUYET S. (1991) - Bryozoan masses in the Miocene-Pliocene and Holocene of France, North Africa and the Mediterranean. Bull. Soc. Sc. Nat. Ouest France, Mém. H.S., 1: 271-279.

MOISSETTE P., DULAI A. and MÜLLER P. (2006) - Bryozoan faunas in the Middle Miocene of Hungary: biodiversity and biogeography. Palaeogeogr. Palaeoclimatol. Palaeoecol., 233: 300-314.

MOISSETTE P., DULAI A., ESCARQUEL G., KAZMER M., MULLER P. and SAINT-MARTIN J.P. (2007) - Mosaic of environments recorded by bryozoans faunas from the Middle Miocene of Hungary. Palaeogeogr. Palaeoclimatol. Palaeoecol., 252: 535-556.

MORRIS P.A. (1979) - Pacific Coast Celleporina Gray (1848): fossil and recent. In: Advances in Bryozoology (eds. G.P. Larwood and M.B. Abbott): 467-489. Academic Press, London.

NOVOSEL M., OLUJIC G., COCITO S. and POZAR-DOMAC A. (2005) - Submarine freshwater springs in the Adriatic Sea: a unique habitat for the bryozoans Pentapora fascialis. In: Proceedings of the Thirteenth International Bryozoology Association Conference Concepcion/Chile/ January 11-16, 2004, Bryozoan Studies 2004 (eds. P.N. Wyse Jackson, J.M. Cancino and H.I. Moyano G.): 218-221. Taylor and Francis.

OLSZEWSKI S. (1876) - Rys geologiczny północno wschodniej części Podola austriackiego. Akad. Um. w Krakowie. Spraw. Kom. Fizyjogr., 10: $115-253$.

PARUCH-KULCZYCKA J. (1994) - Algae in the Sarmatian deposits from Machów outcrop and from the boreholes Jamnica M-83 and S-119 (Carpathian Foredeep). Geol. Quart., 38 (4): 571-576.

PERYT D. and JASIONOWSKI M. (2012) - Sarmatian foraminiferal assemblages of cavern fillings in the Badenian reefs of Medobory (Polupanivka, western Ukraine). Biul. Państw. Inst. Geol., 449: 175-184.

POKORNY V. (1948) - The alga Chalmasia Morelleti n. sp, in the Czechoslovak Sarmatian. Rozpr. Cs. Akad. Ved a Umeni, Trida II, 58: 1-7.

POUYET S. (1973) - Révision systématique des cellépores (Bryozoa, Cheilostomata et des especes fossiles européennes. Analyse de quelques populations a Cellépores dans le Néogene du Bassin Rhodanien. Doc. Lab. Géol. Fac. Sc. Lyon, 55.

REGUANT S. and ZAMARREÑO I. (1987) - Bryozoan bioherms on the Mediterranen continental shelf (Northeastern Spain). In: Bryozoa:
Present and Past (ed. J.R.P. Ross): 229-236. Bellingham, Western Washington University.

REGUANT S.J., FERNÁDEZ J., RODRÍQUEZ-FERNÁNDEZ J. and SERRA-KIEL J. (1991) - Bryozoan biofacies, zoarial forms and sedimentary environments in the Tertiary of Spain. Bull. Soc. Sc. Nat. Ouest France, Mém. H.S., 1: 361-370.

REUSS A. (1869) - Über tertiäre Bryozoen von Kischenew in Bessarabien. Sitz. Ber. K. Akad. Wiss., Math.-Naturwiss. Cl., 60 (3), 1 Abtlg.

STACH L.W. (1936) - Correlation of zoarial form with habitat. J. Geol., 44: 60-65.

STANCU J. and TATOU E. (1974) - Dasycladaceae der sarmatischen Ablagerungen. In: Chronostratigraphie und Neostratotypen (eds. A. Papp, F. Marinescu and J. Senes). Miozän der Zentralen Paratethys. M5 Sarmatien der Slowak. Akad. Wissensch., 4: 606-623.

STUDENCKA B. and JASIONOWSKI M. (2011) - Bivalves from the middle Miocene reefs of Poland and Ukraine: a new approach to Badenian/Sarmatian boundary in the Paratethys. Acta Geol. Pol., 61 (1): 79-114.

TAYLOR P.D., HARA U. and JASIONOWSKI M. (2006) - Unusual early development in a cyclostome bryozoan from the Ukrainian Miocene. Linzer Biol. Beitr., 38 (1): 55-64.

TEISSEYRE W. (1884) - Der podolische Hügelzug der Miodoboren als ein sarmatisches Bryozoen-Riff. Jb. Geol. R.-A., 34: 299-312.

TEISSEYRE W. (1895) - O charakterze fauny kopalnej Miodoborów. Rozpr. Wydz. Mat.-Przyr. Akad. Umiej., 30: 1-11.

TÓTH E., GÖRÖG A., LECUYER CH., MOISSETTE P., BALTER V. and MONOSTORI M. (2010) - Palaeonvironmental reconstruction of the Sarmatian Central Paratethys based on palaeontological and geochemical analyses of foraminifera, ostracods, gastropods and rodent. Geol. Mag., 147: 299-314.

VÁVRA N. (1979) - Die Bryozoenfaunen des österreichischen Tertiärs. N. Jb.Geol. Paläont. Abh., 157: 366-391.

VEJS O.B. (1988) - Miotsenovye mshanki Severnogo Kaukaza i Kryma. Nauka, 232: 1-101. Moskwa.

ZÁGORŠEK K. (2007) - A new Miocene Bryozoa from the Sarmatian of the Danube basin. N. Jb. Geol. Paläont. Abh., 243 (3): 299-303.

ZÁGORŠEK K. and FORDINAL F. (2006) - Lower Sarmatian Bryozoa from brackish sediments in the northern part of the Danube Basin (Dubova, Slovakia). Linzer Biol. Beitr., 38 (1): 93-99.

ZÁGORŠEK K., SILYE L. and SZABO B. (2008) - New Bryozoa from Sarmatian (Middle Miocene) deposits of the Cerne-Strei Depression, Romania. Studia Univ. Babes-Bolyai, Geol., 52: 25-29. 